\title{
PENGGUNAAN METODE "PERANG MENTAL MATEMATIKA" DENGAN MENGGUNAKAN MEDIA KARTU PECAHAN PADA MATERI PENJUMLAHAN BILANGAN PECAHAN
}

\author{
Indah Suciati \\ Program Studi Pendidikan Matematika, FKIP, Universitas Alkhairaat. \\ ndahmath@gmail.com
}

\begin{abstract}
ABSTRAK
Bilangan pecahan merupakan himpunan bagian dari himpunan bilangan real. Meskipun bentuknya sederhana dan sering digunakan dalam kehidupan sehari-hari, namun materi tentang bilangan pecahan khususnya pada penjumlahan bilangan pecahan masih tergolong cukup rumit bagi peserta didik. Untuk mengatasi hal tersebut diberikan solusi berupa metode "perang mental matematikas". Perang Mental Matematika merupakan penyajian cara yang cepat, menarik, dan interaktif bagi peserta didik untuk mempraktikkan masalah dengan variabel, persamaan, dan jawabannya. Adapun langkah-langkah metode "perang mental matematika", yaitu: (1) meninjau kembali kartu permainan, (2) meninjau permainan kartu perang tradisional dan menjelaskan aturan dan prosedurnya, (3) mengelompokkan siswa secara berpasangan, (4) menyediakan tiap pasangan dengan kartu set pecahan untuk dibagi secara merata, (5) mengingatkan peserta didik untuk tidak membuka kartu hingga permainan dimulai dan (6) memulai permainan.
\end{abstract}

Kata kunci : Metode, Perang Mental Matematika, Kartu Pecahan, Penjumlahan, Pecahan.

\begin{abstract}
Fractions are a subset of a set of real numbers. Although the form is simple and often used in everyday, but the material about fractions especially in the addition of fraction numbers is still complicated for students. To overcome this problem, a solution is given in the form of the method of "Mathematical Mental Wars ". Mathematical Mental Wars is the presentation of a fast, interesting, and interactive way for students to practice problems with variables, equations, and answers. The steps of the method of " Mental Wars Mathematics ", namely: (1) reviewing game cards, (2) reviewing traditional war card games and explaining the rules and procedures, (3) grouping students in pairs, (4) providing each pair with The set of fractional cards to be shared equally, (5) reminds students not to open cards until the game starts and (6) starts the game.
\end{abstract}

Keywords: Method, Mathematical Mental Wars, Fraction Cards, Addition, Fractions.

\section{PENDAHULUAN}

Bilangan pecahan merupakan himpunan bagian dari himpunan bilangan real. Meskipun bentuknya sederhana dan sering digunakan dalam kehidupan sehari-hari, namun materi tentang bilangan pecahan khususnya pada penjumlahan bilangan pecahan masih tergolong cukup rumit bagi peserta didik. Seperti yang dikemukakan oleh Suciati \& Wahyuni (2018) bahwa kesalahan konsep sebesar 80,70\%, kesalahan prinsip sebesar $13,16 \%$, dan kesalahan perhitungan sebesar $6,15 \%$ pada operasi penjumlahan pecahan. Selanjutnya, Suciati (2018) juga mengemukakan lagi bahwa pada operasi penjumlahan pecahan pada soal cerita, kesalahan yang paling sering dilakukan adalah process skills errors 
sebesar $49,23 \%$. Sejalan dengan pendapat tersebut, Saparwadi, dkk (2017) menyatakan bahwa kesalahan yang ditemukan pada hasil kerja peserta didik dalam menyelesaikan operasi penjumlahan bilangan pecahan dan operasi bilangan pecahan terkait reversibilitas. Sedangkan Menurut Herna (2017) bahwa Kesalahan pada Operasi Penjumlahan Pecahan seperti menjumlahkan pembilang dengan pembilang dan penyebut dengan penyebut, kesalahan dalam menyamakan penyebut, kesalahan dalam membentuk pecahan senilai, dan kesalahan dalam menyederhanakan penyebut. Hal yang sama juga dinyatakan oleh Nuraini, dkk (2016) bahwa kesalahan peserta didik pada operasi penjumlahan pecahan mencapai $63,3 \%$ yang diantaranya merupakan kesalahan konsep seperti dalam hal kurang memahami KPK, salah dalam menentukan pembilang baru, dan menyamakan penyebut.

Berdasarkan masalah di atas, maka diberikan solusi berupa metode "perang mental matematika". Perang Mental Matematika merupakan penyajian cara yang cepat, menarik, dan interaktif bagi peserta didik untuk mempraktikkan masalah dengan variabel, persamaan, dan jawabannya. Peserta didik yang bermain Perang Mental Matematika memproses operasi pecahan secara mental. metode ini juga merupakan cara yang baik untuk mengenalkan peserta didik pada operasi pecahan. Permainan Perang Mental Matematika mengembangkan kapasitas peserta didik untuk dapat berpikir kritis dan melatih kelancaran mereka pada operasi pecahan. Peserta didik ditantang untuk menggunakan metode tersebut dengan menggunakan strategi secara tepat.

Adapun langkah-langkah metode "perang mental matematika", yaitu: (1) meninjau kembali kartu permainan dan menghitung banyaknya kartu sejumlah 36 buah, (2) meninjau permainan kartu perang tradisional dan menjelaskan aturan dan prosedurnya dengan permainan Perang Mental Matematika, (3) mengelompokkan siswa secara berpasangan, (4) menyediakan tiap pasangan dengan kartu set pecahan untuk dibagi secara merata, (5) mengingatkan peserta didik untuk tidak membuka kartu hingga permainan dimulai dan (6) memulai permainan.

Penerapan metode "perang mental" memberikan peluang kepada peserta didik untuk terlibat dalam pemikiran kreatif dan ekspresi diri. Hal ini sesuai dengan pendapat Ausubel tentang belajar bermakna (Dahar, 2011) bahwa belajar bermakna ialah proses yang mengaitkan informasi baru pada konsep-konsep yang relevan yang terdapat dalam struktur kognitif seseorang. Metode ini sejalan dengan pendekatan Bruner didasarkan pada dua asumsi terhadap belajar, yaitu (a) perolehan pengetahuan ialah proses interaktif, dan (b) seseorang mengkonstruksi pengetahuannya dengan cara menghubungkan informasi yang masuk dengan informasi yang disimpan sebelumnya. Sejalan pula dengan pendapat Gagne bahwa seseorang dikatakan belajar suatu konsep jika ia dapat mendemonstrasikan arti kelas tertentu tentang suatu objek, kejadian atau hubungan (Dahar, 2011). Berdasarkan beberapa teori di atas, maka disimpulkan bahwa metode "perang mental matematika" dapat digunakan pada materi operasi penjumlahan bilangan pecahan.

\section{PEMBAHASAN}

\section{A. Belajar Pengetahuan Prosedural}

Pengetahuan prosedural disajikan oleh produksi, yakni pengetahuan "bagaimana melakukan sesuatu". Produksi yang dimaksudkan ialah aturan-aturan pada kondisi-aksi, artinya produksi memprogram terjadinya suatu aksi-aksi pada kondisi tertentu. Pengetahuan prosedural bukan merupakan pemanggilan informasi, melainkan transformasi suatu informasi. Pengetahuan prosedural terbagi dua bentuk, yaitu:

a. Prosedur pengenalan-pola.

Prosedur pengenalan-pola didasari pada kemampuan dalam mengenal dan mengklarifikasikan pola stimulus eksternal dan internal. Prosedur pengenalan pola menggunakan generalisasi dan hanya melibatkan satu aksi. Dalam generalisasi, seleksi dan urutan contoh merupakan hal penting dalam meningkatkan kemungkinan bahwa peserta didik akan membentuk 
produksi pengenalan-pola yang benar. Dalam diskriminasi, hal yang penting adalah seleksi dan urutan noncontoh.

b. Prosedur urutan-aksi

Prosedur urutan-aksi didasari pada kemampuan dalam melakukan urutan operasi terhadap simbol. Pada prosedur urutan-aksi seluruhnya melibatkan lebih dari satu aksi. Agar urutan aksi itu berguna, aksi hendaknya terjadi pada kondisi tertentu. Jadi, prosedur urutanaksi ialah urutan aksi digabungkan dengan prosedur pengenalan-pola. Karena prosedur pengenalan-pola membantu mempersiapkan urutan aksi yang akan datang. Kita mengklasifikasikan hal-hal untuk membantu dalam membuat prediksi atau melaksanakan aksi.

Menurut Anderson (Dahar, 2011:58) bahwa proses perubahan tindakan yang dibimbing oleh pengetahuan deklaratif ke tindakan suatu urutan aksi yang dibimbing oleh pengetahuan prosedural disebut kompilasi pengetahuan. Kompilasi pengetahuan ialah proses pembentukan suatu penyajian untuk urutan aksi yang menuju pada tindakan yang tepat dan lancar. Kompilasi pengetahuan terbagi atas dua subproses yaitu proseduralisasi dan komposisi.

a. Proseduralisasi adalah pengguguran stimulus dari pengetahuan deklaratif. Ada dua langkah yang terjadi selama proseduralisasi, yaitu menciptakan suatu penyajian proporsional dan menciptakan satu produksi untuk menyajikan setiap langkah urutan aksi.

b. Komposisi adalah penggabungan beberapa prosedur menjadi satu prosedur. Agar terjadi komposisi, suatu urutan dari dua produksi harus aktif dalam memori kerja di waktu yang sama. System akan memperhatikan bahwa aksi dari produksi pertama menimbulkan kondisi untuk produksi kedua, sehingga produksi baru terbentuk.

Walaupun strategi mengajar untuk generalisasi, diskriminasi, proseduralisasi dan komposisi umumnya berbeda, namun strategi latihan yang diikuti dengan umpan balik dapat digunakan untuk setiap macam pengetahuan prosedural. Apabila prosedur itu merupakan pengenalan-pola, kesempatan untuk mengklarifikasikan contoh-contoh baru dari pola hendaknya diberikan. Jika prosedur itu merupakan urutan-aksi, hendaknya soal-soal berupa aplikasi prosedur dan umpan balik,sehingga menunjukkan secara tepat dalam hal apa itu tidak betul atau secara tepat bagaimana cepatnya suatu prosedur yang betul diterapkan. Bentuk soal yang disajikan dan sifat umpan balik berbeda, tergantung pada proses belajar yang dilakukan. Jika proseduralisasi umpan balik tentang ketepatan lebih sesuai dibandingkan umpan balik tentang kecepatan dan perhatian harus diberikan pada pengurutan soal-soal praktis hingga soal yang menggunakan keterampilan yang lebih kompleks . Sedangkan untuk komposisi, umpan balik kecepatan lebih sesuai dan soal yang serupa hendaknya diberikan persamaan. Untuk generalisasi, latihan mengenai contohcontoh yang sangat berbeda dalam atributatribut yang tidak relevan harus diberikan, sedangkan untuk diskriminasi, latihan tentang contoh dan noncontoh diperlukan.

\section{B. Teori Belajar Yang Mendukung}

Berikut ini adalah teori belajar menurut para ahli yang memfokuskan kepada pengetahuan prosedural. Adapun pendapat para ahli tersebut antara lain: Bruner, Ausubel, dan Gagne.

Bruner memusatkan pada masalah apa yang dilakukan manusia dengan informasi yang diterimanya dan apa yang dilakukannya setelah memperoleh informasi tersebut. Hal yang penting baginya adalah bagaimana cara memilih, mempertahankan, dan mentransformasi informasi secara aktif. Pendekatan Bruner terhadap belajar didasarkan pada dua asumsi, yaitu (a) perolehan pengetahuan merupakan suatu proses interaktif, dan (b) orang mengkonstruksi pengetahuannya dengan menghubungkan informasi yang masuk dengan informasi yang disimpan sebelumnya. Menurut Bruner (Dahar, 2011:77) bahwa belajar melibatkan tiga proses yang berlangsung hampir bersamaan. Ketiga proses itu, adalah: (1) memperoleh informasi baru, (2) transformasi informasi, dan (3) menguji relevansi dan ketepatan pengetahuan. Bruner juga mengemukakan 
tiga sistem keterampilan, yaitu: (1) tahap enaktif, (2) tahap ikonik, dan (3) tahap simbolik. Model instruksional kognitif yang sangat berpengaruh dari Jerome Bruner dikenal dengan belajar penemuan. Menurut Bruner bahwa belajar penemuan adalah usaha yang dilakukan secara aktif dan mandiri dalam mencari pemecahan masalah serta pengetahuan yang menyertainya, sehingga menghasilkan pengetahuan yang benar-benar bermakna. Bruner menyarankan agar peserta didik hendaknya belajar melalui partisipasi secara aktif dengan konsep dan prinsip sehingga mereka memperoleh pengalaman dan melakukan eksperimen yang mengizinkan mereka untuk menemukan prinsip itu sendiri.

Menurut Ausubel (Dahar, 2011) bahwa belajar dikelompokkan ke dalam dua dimensi, yaitu: (1) dimensi pertama berhubungan dengan cara informasi atau materi pelajaran yang disajikan pada peserta didik melalui penerimaan atau penemuan, (2) dimensi kedua menyangkut bagaimana cara peserta didik dapat mengaitkan informasi pada struktur kognitif yang telah ada. Inti teori Ausubel tentang belajar adalah belajar bermakna. Belajar bermakna merupakan suatu proses dikaitkannya informasi baru pada konsep-konsep yang relevan yang terdapat dalam struktur kognitif seseorang. Faktor-faktor utama yang mempengaruhi belajar bermakna ialah struktur kognitif yang ada, stabilitas, dan kejelasan pengetahuan pada waktu tertentu. Sifat-sifat struktur kognitif menentukan validitas dan kejelasan arti-arti yang timbul saat informasi baru masuk ke dalam struktur kognitif, demikian juga sifat proses interaksi yang terjadi. Bila struktur kognitif itu stabil, jelas dan diatur dengan baik, arti yang sahih dan jelas atau tidak meragukan akan timbul dan cenderung bertahan.

Menurut Gagne (Dahar, 2011) bahwa ada lima kemampuan dikatakan sebagai hasil belajar yaitu keterampilan intelektual, strategi kognitif, sikap, informasi verbal, dan keterampilan motorik. Keterampilan intelektual memungkinkan seseorang berinteraksi dengan lingkungannya dengan penggunaan simbol-simbol atau gagasangagasan. Strategi kognitif merupakan keterampilan khusus yang mempunyai kepentingan tertentu bagi belajar dan berpikir. Informasi verbal disimpan sebagai jaringan proposisi. Sikap merupakan pembawaan yang dapat dipelajari dan dapat mempengaruhi perilaku seseorang terhadap suatu informasi. Sedangkan keterampilan motorik merupakan suatu kegiatan motorik yang digabungkan dengan keterampilan intelektual.

\section{Perang Mental Matematika}

Perang Mental Matematika merupakan penyajian cara yang cepat, menarik, dan interaktif bagi peserta didik untuk mempraktikkan masalah dengan variabel, persamaan, dan jawabannya. Peserta didik yang bermain Perang Mental Matematika memproses operasi pecahan secara mental. metode ini juga merupakan cara yang baik untuk mengenalkan peserta didik pada operasi pecahan.

Permainan Perang Mental Matematika mengembangkan kapasitas peserta didik untuk dapat berpikir kritis dan melatih kelancaran mereka pada operasi pecahan. Peserta didik ditantang untuk menggunakan metode tersebut dengan menggunakan strategi secara tepat.

Sebelum memulai Perang Mental Matematika, peserta didik berkumpul dalam kelompok kecil atau berpasangan dan tiap kelompok atau pasangan diberi setumpuk kartu permainan pecahan yang berjumlah 36 buah. Tiap kartu memiliki nilai angka yang merupakan bilangan pecahan. Cara permainan ini dengan meletakkan dua kartu secara bersamaan yang nilainya ketika dijumlahkan bernilai 1. Permainan ini diawali dengan mengocok kartu permainan, kemudian dibagi kepada anggota pemain hingga kartu tersebut habis. Selanjutnya setiap pemain secara bergantian mengambil kartu dari lawan dan memeriksa kartunya jika ada sepasang kartu yang bernilai 1 dan meletakkan di tengah antara para pemain. Permainan ini berlanjut hingga salah seorang peserta didik sudah tidak memiliki kartu lagi. Permainan ini melatih daya pikir dan ketelitian peserta didik. Adapun langkah-langkah metode "Perang Mental Matematika", yaitu:

1. Meninjau kembali kartu permainan dan menghitung banyaknya kartu sejumlah 36 buah. 
2. Meninjau permainan kartu perang tradisional dan menjelaskan aturan dan prosedurnya dengan permainan Perang Mental Matematika.

3. Mengelompokkan siswa secara berpasangan.

4. Menyediakan tiap pasangan dengan kartu set pecahan untuk dibagi secara merata.

5. Mengingatkan peserta didik untuk tidak membuka kartu hingga permainan dimulai.

6. Memulai permainan.

D. Kaitan Teori Belajar dengan "Perang Mental Matematika"

Suatu materi akan senantiasa diingat jika meninggalkan kesan kepada peserta didik. Sehingga itu, akan dipaparkan kaitan teori belajar dengan metode "Perang Mental Matematika" agar materi yang diajarkan dapat meninggalkan kesan yang bermakna pada peserta didik.

Metode "Perang Mental Matematika" sejalan dengan pendapat Bruner (Dahar, 2011) yang menyatakan bahwa pengajaran/instruksi hendaknya mencakup (1) pengalaman optimal bagi peserta didik agar ingin dan bisa belajar, (2) penstrukturan pengetahuan untuk pemahaman optimal, (3) perincian urutan penyajian materi secara optimal, dan (4) bentuk dan pemberian reinforcement. Tujuan belajar menurut Bruner adalah untuk mendapatkan pengetahuan dengan suatu cara yang mampu melatih kemampuan intelektual peserta didik serta merangsang keingintahuan dan memotivasi kemampuan mereka. Selain itu, pengetahuan yang diperoleh menunjukkan beberapa kebaikan, seperti: (a) pengetahuan dapat bertahan lama atau lebih mudah diingat, (b) hasil belajar mempunyai efek transfer yang lebih baik. Dengan kata lain, konsep-konsep yang dijadikan milik kognitif peserta didik lebih mudah diterapkan pada suatu situasi baru, dan (c) meningkatkan penalaran peserta didik dan kemampuan berpikir secara bebas. Hal ini dapat terlihat pada metode "Perang Mental Matematika", dimana peserta didik membuat suatu strategi dalam memecahkan masalah matematika secara tepat dan akurat. Metode ini dapat membuat peserta didik dapat mengembangkan kapasitas berpikir di luar kepala dan melatih kelancaran saat menggunakan angka, simbol maupun persamaan. Peserta didik juga memproses operasi matematika secara mental untuk mengenalkan konsep variable dan persamaan yang merupakan inti aljabar. Metode "Perang Mental Matematika"sejalan pula dengan belajar sebagai proses kognitif menurut Bruner, dimana:

1) Memperoleh informasi baru,

2) Transformasi informasi.

3) Menguji relevansi dan ketepatan pengetahuan.

"Perang Mental Matematika" sejalan juga dengan pendapat Ausubel (Dahar, 2011:99) yang mengemukakan prasyarat belajar bermakna, yaitu:

1) Materi yang diajarkan harus bermakna secara potensial (memiliki kebermaknaan logis dan gagasan yang relevan harus terdapat pada struktur kognitif)

2) Peserta didik harus melaksanakan tujuan belajar bermakna. Jadi, peserta didik memiliki kesiapan dan niat untuk belajar bermakna. Tujuan peserta didik ialah faktor utama dalam belajar bermakna.

Pemaparan tersebut sejalan dengan pemilihan materi yang tepat untuk digunakan pada metode "Perang Mental Matematika", sehingga itu materi yang dipilih adalah materi yang memuat pengetahuan prosedural. Ausubel berpendapat mengenai penerapan teorinya dalam mengajar (Dahar, 2011) bahwa apa yang telah diketahui peserta didik adalah faktor terpenting yang mempengaruhi belajar. Jadi, agar belajar bermakna terjadi, maka konsep atau informasi baru harus dikaitkan dengan informasi yang sudah ada pada struktur kognitif peserta didik. Selain itu, prinsip yang perlu diperhatikan adalah (1) pengaturan awal, (2) diferensiasi progresif, (3) penyesuaian integratif, dan (4) belajar superordinat. Keempat prinsip tersebut, sesuai dengan langkah-langkah yang diterapkan pada "Satu Gambar, Seribu Kata".

Bertolak dari model yang pemrosesan informasi oleh Gagne, Gagne mengemukakan lima kemampuan sebagai hasil belajar, yaitu: (1) keterampilan intelektual, (2) strategi kognitif, (3) sikap, 
(4) informasi verbal, (5) keterampilan motorik.

\section{E. Penggunaan Metode "Perang Mental \\ Matematika" Pada Materi \\ Penjumlahan Bilangan Pecahan}

Sesuai dengan pendapat beberapa pendapat para ahli mengenai teori belajar, maka penggunaan metode "Perang Mental
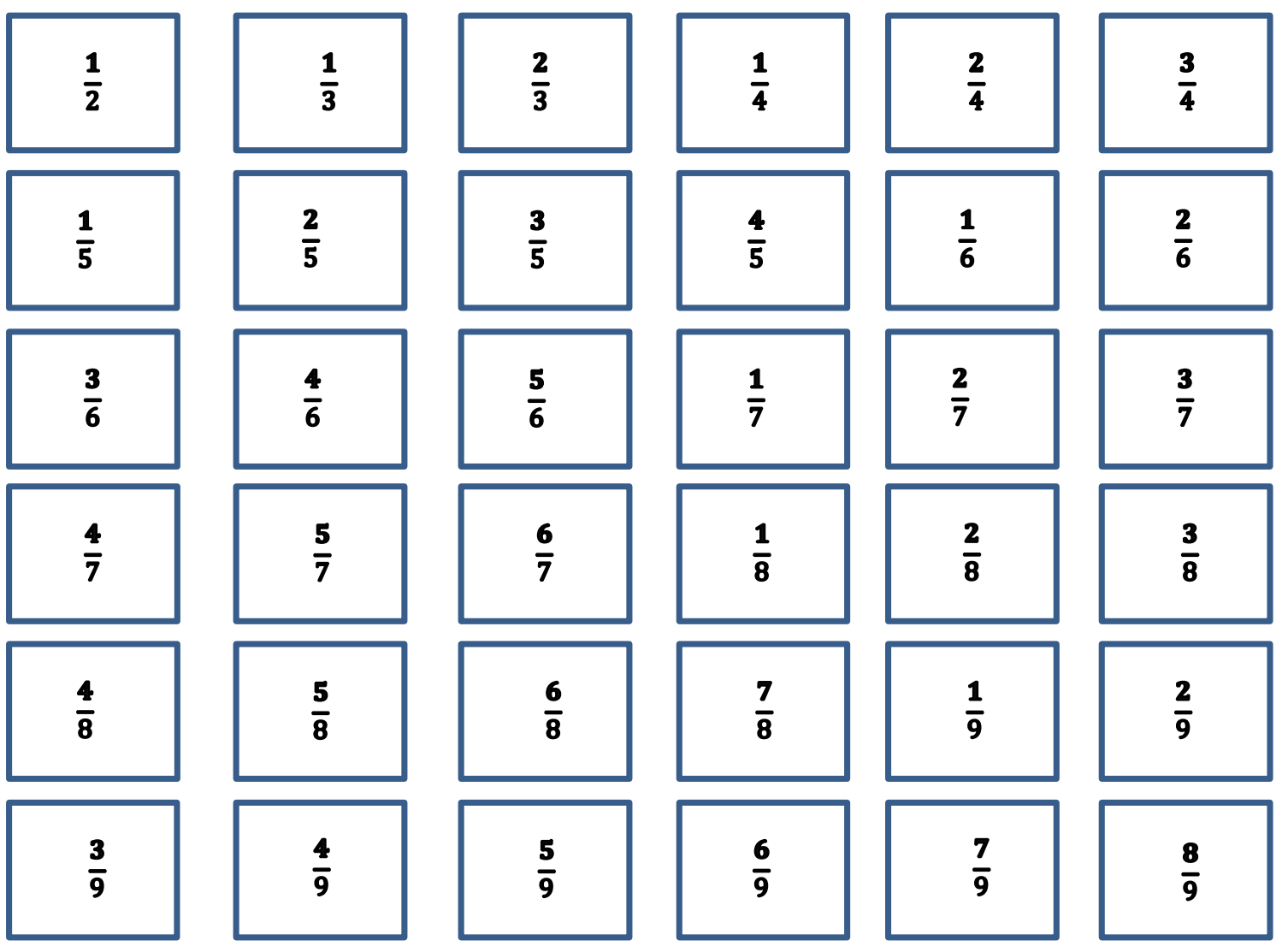

Gambar 1: Kartu Joker Pecahan berjumlah 36 buah

Langkah 2: Meninjau permainan kartu perang tradisional dan menjelaskan aturan dan prosedurnya dengan permainan Perang Mental Matematika.

Dalam permainan ini, aturan yang diterapkan yaitu hampir sama dengan permainan kartu pada kartu joker dimana pada aturan permainan kartu joker yang dimaksud adalah ketika 2 kartu memiliki gambar angka sama, maka kedua kartu tersebut diturunkan. Pada permainan ini, memiliki aturan yang hampir sama, yaitu: a. Mengocok kartu joker pecahan terlebih dahulu, kemudian dibagikan kepada seluruh anggota yang bermain pada kelompok tersebut.

b. Kartu dibagikan seluruhnya hingga tidak bersisa.

c. Memeriksa kartu jika ada yang dapat diturunkan. Dua buah kartu dapat diturunkan jika jumlah kedua kartu bernilai 1 . 

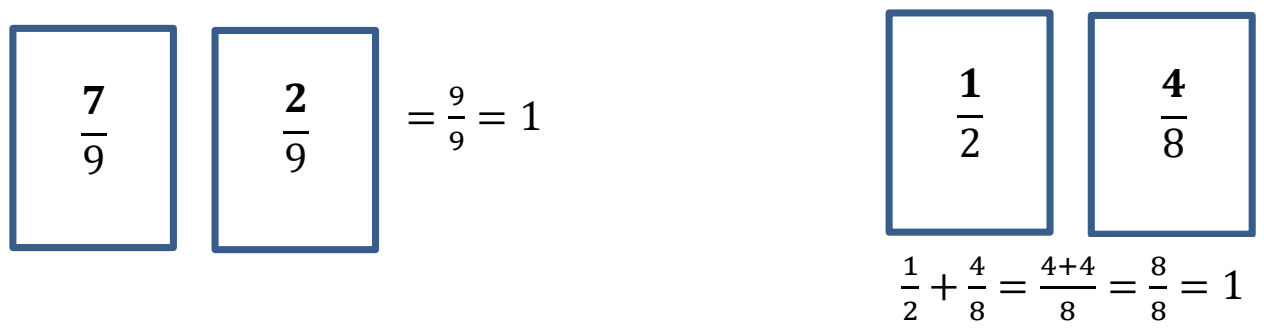

Gambar 2: Contoh aturan permainan

d. Ketika tidak adalagi kartu yang dapat diturunkan, maka selanjutnya untuk pemain pertama mengambil 1 kartu pada pemain yang lain sesuai dengan jalur yg telah disepakati, misalnya menggunakan jalur yang berlawanan dengan arah jarum jam

e. Selanjutnya, memeriksa kembali kartu jika ada kartu yang bisa diturunkan.

f. Jika tidak adalagi kartu yang bisa diturunkan, dilanjutkan ke pemain kedua.

g. Permainan berlanjut hingga terdapat pemain yang sudah tidak memiliki kartu lagi.

h. Pemain yang tidak memiliki kartu dianggap sebagai pemenang.

Langkah 3: Mengelompokkan siswa secara berpasangan.

Pengelompokkan siswa secara berpasangan dapat dilakukan antara $2-4$ orang dalam 1 kelompok. Tergantung dari jumlah siswa dalam 1 kelas. Pengelompokkan dapat dilakukan sesuai pertimbangan guru.

Langkah 4: Menyediakan tiap pasangan/kelompok dengan kartu set pecahan untuk dibagi secara merata.

Setiap kelompok yang telah dibentuk, kemudian diberikan 1 set kartu pecahan yang berisikan 36 jumlah kartu yang kemudian akan dimainkan oleh anggota kelompok tersebut.

Langkah 5: Mengingatkan peserta didik untuk tdk membuka kartu hingga permainan dimulai.

Setelah kartu set pecahan dibagikan kepada semua kelompok, kemudian secara bersamaan semua kelompok memulai permainan.

Langkah 6: Memulai permainan.

\section{KESIMPULAN}

Bilangan pecahan merupakan himpunan bagian dari himpunan bilangan real. Meskipun bentuknya sederhana dan sering digunakan dalam kehidupan seharihari, namun materi tentang bilangan pecahan khususnya pada penjumlahan bilangan pecahan masih tergolong cukup rumit bagi peserta didik. Perang Mental Matematika merupakan penyajian cara yang cepat, menarik, dan interaktif bagi peserta didik untuk mempraktikkan masalah dengan variabel, persamaan, dan jawabannya. Peserta didik yang bermain Perang Mental Matematika memproses operasi pecahan secara mental. metode ini juga merupakan cara yang baik untuk mengenalkan peserta didik pada operasi pecahan. Permainan Perang Mental Matematika mengembangkan kapasitas peserta didik untuk dapat berpikir kritis dan melatih kelancaran mereka pada operasi pecahan. Peserta didik ditantang untuk menggunakan metode tersebut dengan menggunakan strategi secara tepat.

Adapun langkah-langkah metode "perang mental matematika", yaitu: (1) meninjau kembali kartu permainan dan menghitung banyaknya kartu sejumlah 36 buah, (2) meninjau permainan kartu perang tradisional dan menjelaskan aturan dan prosedurnya dengan permainan Perang Mental Matematika, (3) mengelompokkan siswa secara berpasangan, (4) menyediakan tiap pasangan dengan kartu set pecahan untuk dibagi secara merata, (5) mengingatkan peserta didik untuk tidak membuka kartu hingga permainan dimulai dan (6) memulai permainan. Penggunaan metode "perang mental matematika" ini dapat dipadukan dengan model pembelajaran yang dianggap cocok. Dapat dipadukan dengan model pembelajaran 
kooperatif atau model pembelajaran lainnya. Guru juga dapat memberikan reward atau latihan lanjutan untuk memantapkan pengetahuan dan kecakapan peserta didik. Selain itu, penggunaan metode "perang mental matematika" dapat pula digunakan pada materi lain yang memfokuskan pada prosedural matematika.

\section{DAFTAR PUSTAKA}

Dahar, Ratna W. (2011). Teori-teori Belajar dan Pembelajaran. Jakarta: Erlangga

Herna. (2017). Analisis Kesalahan Matematika Siswa dalam Menyelesaikan Soal Operasi Penjumlahan Pecahan Bentuk Aljabar. Jurnal Pendidikan PEPATUDZU Media Pendidikan dan Sosial Kemasyarakatan, 13(1).

https://journal.lppmunasman.ac.id/index.php/pepatudzu/a rticle/view/176/168

Nuraini, Ni Luh S. Suhartono \& Yuniawatika. (2016). Kesalahan Siswa pada Operasi Penjumlahan dan Pengurangan Pecahan di Kelas VI Sekolah Dasar. Tahun 25, Nomor 2, November 2016, hlm: 168-175 (Online).

http://journal2.um.ac.id/index.php/sd/article /download/1337/703

Ollerton, Mike. (2010). Panduan Guru Mengajar Matematika. Jakarta: Erlangga

Saparwadi, Lalu.,Purnawati, Baiq., \& Erlian, B. Puspa. (2017). Siswa dalam Menyelesaikan Soal Operasi Penjumlahan pada Bilangan Pecahan dan Reversibilitas. Jurnal Pendidikan Matematika, 3(2), hal 60-66.

http://riset.unisma.ac.id/index.php/jpm/artic le/view/715/709

Silver, Harvey F., dkk. (2013). Pengajaran Matematika: Kurikulum Inti Bersama, Edisi Kedua. Jakarta: Indeks.

Suciati, Indah \& Wahyuni, Dewi S. (2018). Analisis Kesalahan Siswa dalam Menyelesaikan Soal Matematika pada
Operasi Hitung Pecahan pada Siswa Kelas V SDN Pengawu. Jurnal Penelitian dan Pembelajaran Matematika (JPPM), 11(2), hal. 129144.

Suciati, Indah. (2018). Analisis Kesalahan Siswa dalam Menyelesaikan Soal Cerita pada Operasi Hitung Pecahan Siswa Kelas V SDN Pengawu. Jurnal Ilmiah Pendidikan Matematika "EQUALS", 1(1), hal. 17-29. 